\title{
주거 기회의 분배에 관한 분석
}

\section{민병철*}

이 연구에서는 임차시장에서 주거의 기회가 사회 전체적으로 얼마나 고르게 제공되고 있는지를 분석하였다. 모두가 더 다양한 곳에서 살 수 있는 기회를 누릴 수 있다면 좋 겠지만, 소득과 자산 격차가 존재하는 현실 하에서 그렇지 못하다고 해서 이를 부정적 으로 단정하는 것은 섣부른 판단일 수 있다. 따라서 이 연구에서는 소득과 자산 격차 가 존재하는 현실 하에서 이를 고려한 주거의 기회가 얼마나 고르게 주어지고 있는지, 그 불평등도를 측정하였다. 분석 결과, 전반적인 주거 기회의 불평등도는 감소하고 있 으나, 지역, 연령대 및 가구형태에 따른 불평등도는 높아지고 있는 것으로 나타났다.

핵심어 주거부담, 불평등도, 타일지수, 임차가능분포도

* 한국주택금융공사 주택금융연구원 연구위원, 산업 및 시스템공학박사, bcmin@hf.go.kr

※ 본고의 내용은 필자의 개인 의견으로 한국주택금융공사의 공식적인 견해와 다를 수 있습니다. ※ 본 조사결과는 「통계법」제 3 조 제 1 호 및「동법 시행령」제 2 조 제 5 호에 해당하는 수량적 정보로 서, 통계법 적용대상이 아님을 알려드립니다. 


\section{I . 서론}

성장과 분배는 경제 발전의 방향을 논할 때 항상 등장하는 단어들이다. 일반적으로 모두가 먹 고 살기에 경제가 충분히 발전하지 못하였을 경우 성장을 우선시하고, 경제발전을 통하여 전체 경제규모가 충분히 성장한 후에는 분배를 강조하게 된다. 두 가지 모두 달성해야 할 중요한 가 치이다. 이에 따라 국가는 꾸준히 성장과 분배가 어느 정도 이루어졌는지 점검하고 부족한 부분 을 보완하기 위해 노력한다.

주택시장도 이와 비슷한 관점으로 바라볼 수 있다. 과거에는 우리나라는 주택공급이 절대적 으로 부족하였다. 따라서 주택 공급의 양을 늘리는 것이 절대적인 과제였다. 현재도 수도권의 경우에는 공급이 부족하다는 시각이 우세하긴 하지만, 주택보급률의 꾸준한 상승과 지방시장 미분양 증가 등을 고려하면 이외의 지역에서 공급 자체가 크게 부족하다고는 보기 어렵다. 주택 의 공급 부족 자체가 더 이상 가장 큰 문제가 아니라고 한다면, 주택에 거주할 수 있는 기회가 얼마나 균등하게 제공되고 있는지를 살펴볼 필요가 있다.

이러한 맥락에서, 이 연구에서는 임차시장에서 제공되는 주거 기회의 분배에 대하여 분석하 였다. 일반적으로 분배에 관한 연구들은 소득이나 자산의 분포에 집중되어 왔다. 하지만 주거 기회의 분배는 소득 및 자산의 분배뿐만 아니라 주택 가격의 분포와도 동시에 밀접한 관련이 있 다. 소득의 불균형이 극심해서 저소득층이 많이 있더라도 주택임차가격이 매우 저렴한 사회라 면 주거 기회의 불균형은 그리 크지 않을 수 있다. 가구의 특성 또한 주거 기회의 분배를 분석하 기 위해서는 고려해야 할 요소이다. 지역에 원룸이 대거 공급되더라도 이는 주거를 위해 일정 수준의 넓이를 필요로 하는 4 인 가구에게는 아무런 의미가 없다. 따라서 이 연구에서는 소득과 자산뿐만 아니라 주택시장과 가구의 특성까지 고려하고자 하였다.

II장에서는 연구에 사용된 분석의 출발점인 임차가능지수에 대해 살펴보고, 불평등도를 측정 하기 위하여 개발된 기존의 여러 방법들을 정리한다. 피장에서는 불평등도를 측정하는 방식을 임차시장에 적용하는 방법에 대해 논한다. IV장에서는 분석에 사용할 자료들을 정리하였으며 이를 이용한 결과는 V장에 소개한다. VI장에서는 결론을 짓는다. 


\section{II . 선행연구}

우리나라의 주거 부담을 측정하기 위해 한국주택금융공사에서는 K-HAI(Korea-Housing Affordability Index, 주택구입부담지수), K-HOI(Korea-Housing Opportunity Index, 주 택구입물량지수)의 두 가지 지표를 발표하고 있다. K-HAI는 중위 소득 분위의 가구가 중위 가 격의 아파트를 구입하고자 할 때의 부담을 측정한다. $\mathrm{K}-\mathrm{HOI}$ 는 중위 소득 분위의 가구가 전체 아파트 중 크게 무리하지 않으면서 구입할 수 있는 비중을 계산한다. K-HAI는 가구가 아파트 를 구입하고자 할 때의 금전적 부담을 직접적으로 계산하고, $\mathrm{K}-\mathrm{HOI}$ 는 아파트 매매 시장에서 중위 가구가 부담할 수 있는 아파트의 비율을 계산하므로 가구에게 선택의 폭이 얼마나 넓게 주 어지는지를 측정한다고 볼 수 있다.

$\mathrm{K}-\mathrm{HAI}$ 와 $\mathrm{K}-\mathrm{HOI}$ 는 아파트 매매시장에 대한 정보를 담고 있으나, 주거부담을 많이 느낄 것 으로 추정되는 저소득층은 아파트 매매시장에 참여하기 어려우므로 이들의 부담을 파악하기에 는 무리가 있다. 이들이 주로 참여하는 시장은 매매시장이 아닌 임차시장이다. 해외에서는 임차 시장에서의 주거부담을 측정하기 위해 소득 대비 임대료 비율(rent-to-income ratio, RIR)을 사용한다. 하지만 우리나라에서는 전세와 보증부월세의 존재로 인해 RIR만으로는 임대차시장 의 주거부담을 제대로 분석하기 어렵다. 이에 민병철 외(2018)에서는 한국 임대차시장의 주거 부담을 측정할 수 있는 주택임차가능지수를 개발하였다.

주택임차가능지수는 Gan and Hill(2008)이 제안한 AaR(Affordability at Risk)의 개념을 도입하였다. 주거안정성에 영향을 미치는 금전적 부담은 주택 사용 시점에서의 부담과 주택 취 득 시점에서의 부담으로 나누어 볼 수 있다. 일반적으로 주택 사용 시점에서의 부담은 매매시장 의 PIR(price-to-income ratio)이나 임차시장의 RIR(rent-to-income ratio)을 이용하여 측정한다. Gan and Hill(2008)에서는 주택 사용 시점에서의 부담에만 주목했을 때 놓칠 수 있 는 부담에 대해 지적하며, 주택 취득 시점에서의 부담을 측정하기 위해 각 가구에 대한 $\mathrm{AaR}$ (Affordability at Risk)를 〈식 1)과 같이 정의하고 사회 전체의 부담을 〈식 2〉와 같이 제 시하였다.

$$
\begin{gathered}
\operatorname{AaR}(x)=\int_{x \times A L}^{y_{1}} f(y) d y=1-F(x \times A L) \\
A a R=\int_{x_{0}}^{x_{1}} A a R(x) g(x) d x
\end{gathered}
$$




\section{주백금융영군ㄱ}

$x \times A L: x$ 의 소득을 가진 가구가 부담할 수 있는 주택의 최대가격,

$y_{1}$ : 시장에 존재하는 가장 비싼 주택의 가격, $f(y)$ : 주택의 가격분포, $g(x)$ : 가구의 소득분포

$\mathrm{AaR}((2))$ 은 전체 주택 대비 $x$ 소득의 가구가 부담할 수 없는 주택의 비율(AaR(x), (1))을 산 출한 후, 이를 전 가구에 대하여 누적한 값이다.

$\mathrm{AaR}$ 을 계산하기 위해서는 각 소득분위의 가구가 부담할 수 있는 주택의 최대가격을 도출해 야 하는데, 한국 임대차시장은 전세와 보증부월세의 혼재로 임차료 지불이 저량과 유량의 두 가 지 차원으로 이루어져 가구의 주택 부담여부를 판별하기가 쉽지 않다. 민병철 외(2018)에서는 가구의 주택 부담여부를 판별하기 위하여 다음과 같은 세 부등식을 제안하였다.

$\begin{array}{lrr}\text { 보증금 < 자기자본 }+ \text { 차입 } & \text { (보증금 제약식) } & \langle\text { 식 3〉 } \\ \text { 월세 }+ \text { 주거 관련 부채 이자 }<\text { 가처분소득 } \times \alpha 1) & \text { (월세 제약식) } & \langle\text { 식 4〉 } \\ \text { 가계 전체 이자 상환액 }<\text { 소득 } \times \text { DTI 제한 } & \text { (부채 제약식) } & \langle\text { 식 5〉 }\end{array}$

이 세 식을 모두 만족하는 가구는 해당 주택을 임차가능하다고 판별하고, 각 가구에 대하여 전체 주택 대비 부담할 수 있는 주택의 비율을 계산하였다. 각 가구에 대하여 계산된 이 비율을 그래프로 나타낸 것이 주택임차가능분포도이다. 그리고 이렇게 도출한 분포도의 넓이를 토대로 주택임차가능지수를 계산하였다. AaR과는 달리 부담할 수 없는 주택의 비중이 아닌 부담할 수 있는 주택의 비중을 계산하였다.

주택임차가능지수는 전체 소득분위에 대한 정보를 담기 위해 $\mathrm{AaR}$ 의 개념을 도입하되, 한국 임대차시장의 특수성을 반영하고자 하였다. 또한 $\mathrm{K}-\mathrm{HOI}$ 가 매매시장에 대해 담고 있는 정보와 유사한 정보를 임대차시장에 대하여 제공하고 있다고도 볼 수 있다.

주택금융공사(2018)에서는 주택임차가능지수의 개념을 이용하여 가구 특성별 임차부담의 분석을 시도하였다. 주택임차가능지수는 전체 주택 대비 각 가구가 부담할 수 있는 주택의 비중 을 토대로 계산되기 때문에 각 가구들의 특성을 고려하지 못하여 부담을 왜곡시킬 우려가 존재 한다. 예를 들어, 4 인 가구는 일정 수준의 주거를 위하여 1 인 가구보다는 더 넓은 면적의 주거 지가 필요하다. 하지만 이러한 특성을 고려하지 않은 채 주택임차가능지수를 계산한다면 4인 가구에 대하여도 실제로 거주하기 힘들지만 가격은 낮은 원룸 등을 모두 포함시켜 부담을 측정 하기 때문에 그 부담이 과소평가될 위험이 존재한다. 반대로, 1 인 가구의 경우에는 넓은 거주지

1) $\alpha$ : 소득 대비 월세 및 주거관련 부채이자(유량) 지출 비율의 상한 
가 필요하지 않음에도 불구하고 지수 산출과정에서 넓은 거주지들을 모두 포함시키기 때문에 부담이 과대평가될 위험이 있다. 주택금융공사(2018)에서는 1 인/2인/3인/4인 가구가 실제로 평균적으로 거주하고 있는 거주지의 넓이 범위를 적정넓이라고 간주하고, 해당 범위 내의 주택 만을 대상으로 주택임차가능지수를 산출하였다.

불평등도의 측정에 대한 선구적인 연구로는 Lorenz(1905)를 꼽을 수 있다. Lorenz(1905)는 부의 집중도를 측정하기 위한 수단으로 로렌츠 곡선을 제안하였다. 이전에는 정해진 소득 구간 에 포함되는 사람의 숫자 혹은 비중을 토대로 부의 집중도를 분석하였다. 하지만 Lorenz (1905)는 이러한 방식으로는 전반적인 부의 수준이 상승하거나 최상위 구간에의 집중도가 높아 지는 경우에 현실을 제대로 분석할 수 없음을 지적하며 인구와 부의 변화를 동시에 고려할 필요 가 있다고 주장하였다. 그는 각 소득 구간에 포함되는 사람의 비중을 통해 인구의 누적비율과, 전체 소득 대비 각 소득 구간이 차지하는 비중을 통해 소득의 누적 점유율을 계산하였다. 이 두 가지 비율의 관계를 통해 부의 분배를 분석하였는데, 이를 그래프로 나타내면 〈그림 1)과 같다.

\section{<그림 1> 로렌츠 곡선}

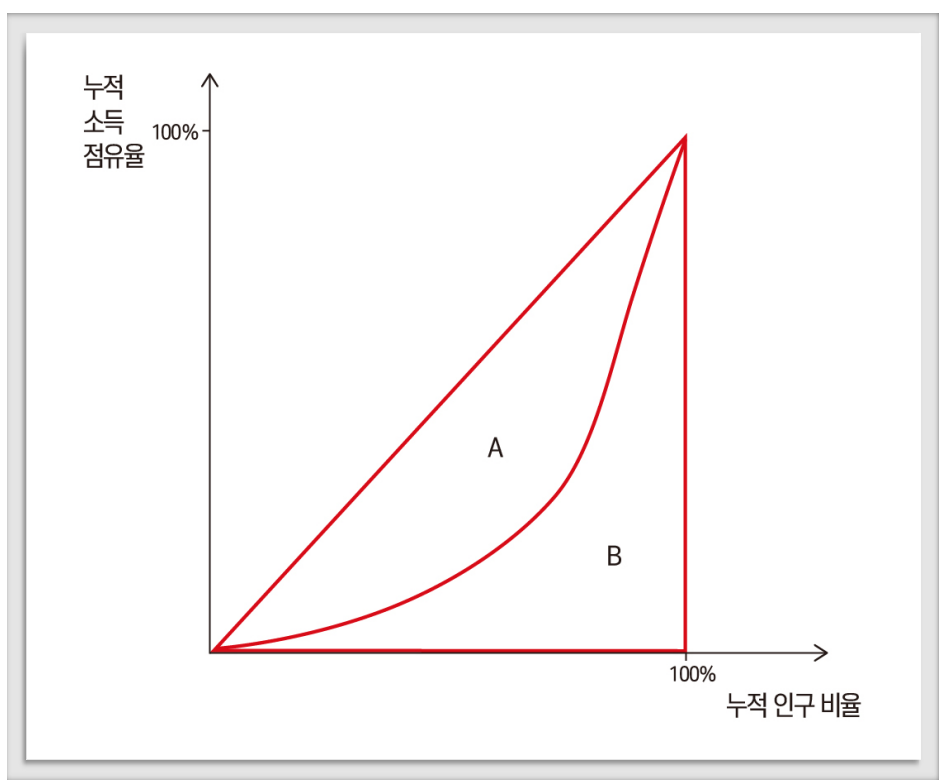

Gini(1912)는 로렌츠 곡선 상에서의 불평등도를 수치로 나타낼 수 있는 지니계수를 제안하 였다. 〈그림 1〉에서 현 상황을 나타내는 그래프의 넓이는 B이며, 가장 이상적이라고 볼 수 있는 경우는 $\mathrm{A}+\mathrm{B}$ 라고 할 때, 지니계수는 $\mathrm{B} /(\mathrm{A}+\mathrm{B})$ 와 같다. 이는 현 상황이 불평등도가 없는 가장 이 


\section{주백금융영군ㄱ}

상적인 경우에서 얼마나 벗어나 있는지를 나타낸다고 볼 수 있다.

Donaldson and Weymark(1980)은 지니계수를 일반화시킨 일반화된 지니(generalized gini)를 제안하였다. 지니계수는 산출과정에서 각 소득분위에 대한 특정 가중치를 부과하게 되 는데, 일반화된 지니는 소득 상위계층 대비 하위계층에 대한 가중치 비율을 조정할 수 있는 장 치를 포함시켰다고 볼 수 있다.

로렌츠 곡선으로부터 도출된 지니계수는 매우 직관적이지만, 사회의 불평등도를 바라보는 시 각을 반영할 수 있는 이론적 기반이 다소 빈약하다. 지수는 복잡한 사회적 현상을 하나의 숫자 로 표현하는 방식이다. 이 과정에서 단순화를 위해 여러 부차적인 요소들은 배제되거나 가정을 통해 무시되는 등 지수의 산출방식에는 그 현상을 바라보는 시각이 반영되어 있다고 볼 수 있 다. 이러한 측면에서 지니계수는 이론적으로 몇 가지 약점을 드러낸다. 예를 들어, 소득 분포가 표준분포를 따르며 평균이 연 4,000만원인 사회를 가정해 보자. 그리고 이 사회에서 연 소득 격차가 100 만원인 두 사람 간 10 만원 만큼 소득의 재분배가 이루어지는데, 세 가지 경우가 있 다고 해 보자. Case A: 소득이 1 억 100 만원인 가구에서 1 억원인 가구로의 10 만원 재분배, Case B: 소득이 4,000만원인 가구에서 3,900만원인 가구로의 10 만원 재분배, Case C: 소득 이 1,100 만원인 가구로부터 1,000 만원인 가구로의 10 만원 재분배. 지니계수는 설계된 방식상 $\mathrm{A}$ 나 $\mathrm{C}$ 의 소득 재분배가 발생하는 것보다 $\mathrm{B}$ 의 소득 재분배가 발생할 때 더 크게 변하게 된다. 이는 누구나 동의할 수 있는 특징이라고는 보기 어렵다. 이에 이론적 바탕에서부터 출발하여 불 평등도를 측정하는 여러 시도들이 있었다.

그 중 한 가지 방법은 사회후생함수(social welfare function, SWF)에 기반하여 불평등도 를 측정하는 것이다. 사회에 존재하는 부의 분포가 사회 전체의 효용에 영향을 미친다고 할 때, 부의 분포와 사회의 효용 간 관계를 수식으로 도출하여 직접적으로 불평등도의 영향을 측정하 는 방식이다. 일반적으로 사용되는 SWF는 5가지 속성을 가지며2), 이러한 SWF에 대하여 Atkinson(1970) 은 앳킨슨 지수를 〈식 6)과 같이 제안하였다. 여기서 $U$ 는 효용함수, $\bar{U}$ 는 효 용함수의 평균값, $\bar{y}$ 는 부의 평균값이다.

$$
A_{\epsilon}=1-\frac{U^{-1}(\bar{U})}{\bar{y}}
$$

2) Individualistic and nondecreasing, symmetric, additive, strictively concave, constant relative inequality aversion 
5 가지 속성을 가진 SWF를 〈식 7〉로 표현할 때, 〈식 6>은 〈식 8〉로 나타낼 수 있다. $y_{i}$ 는 i번 째 사람의 부, $\epsilon$ 는 불평등을 회피하고자 하는 정도(aversion to inequality)를 나타낸다.

$$
\begin{gathered}
U\left(y_{i}\right)=\frac{y_{i}^{1-\epsilon}-1}{1-\epsilon} \\
A_{\epsilon}=1-\left[\frac{1}{n} \sum_{i=1}^{n}\left[\frac{y_{i}}{\bar{y}}\right]^{1-\epsilon}\right]^{\frac{1}{1-\epsilon}}
\end{gathered}
$$

$\mathrm{SWF}$ 방식은 $\epsilon$ 에 따라 현재의 불평등도를 다르게 측정한다는 점에서 사회의 불평등도에 대한 관점이 반영될 수 있다는 장점이 있다.

엔트로피의 개념과 연관된 정보이론(Information theory)에 기초하여 불평등도를 측정할 수 도 있다. 엔트로피의 개념은 열역학에서 탄생하여 분자들의 운동과 같은 과학적 현상을 이해하 는데 사용되며 발전되어 왔다. Fisher(1922)는 엔트로피 개념을 이론통계학에 적용하였고, Shannon(1948)은 이러한 개념을 정보이론과 연계하여 정리하였다. 정보이론을 직관적으로 설명하는 방법은 여러 가지가 있을 수 있지만, 그 중 한 가지 방법은 어떠한 확률변수가 가지는 무작위성을 측정하는 것으로 보는 것이다. 예를 들어, 확률변수 $\mathrm{A}$ 에 대하여 어떤 사건 i가 발생 할 확률이 1 이고 다른 사건들이 발생할 확률이 0 이라고 한다면, 어떤 사건이 발생할지를 확실 히 알 수 있으므로 이 경우에는 무작위성이 없다. 하지만 발생가능한 모든 사건들의 발생확률이 같다면, 어떠한 사건이 발생할지를 예측하기가 매우 어려우므로 무작위성이 높다고 볼 수 있다. 무작위성의 척도라고 볼 수 있는 엔트로피는 〈식 9>와 같이 정의된다. 여기서 $p_{i}$ 는 i사건이 발 생할 확률이며 $h\left(p_{i}\right)$ 는 이 정보에 대한 가치를 나타낸다. $h\left(p_{i}\right)$ 가 가져야할 여러 속성들이 있는 데, 이를 만족시키는 함수의 형태는 로그함수로 알려져 있다. $h\left(p_{i}\right)$ 를 로그함수로 나타내면 엔 트로피의 정의는 〈식 10〉으로 다시 쓸 수 있다.

$$
\begin{gathered}
\text { entropy }=\sum_{i=1}^{n} p_{i} h\left(p_{i}\right) \\
=-\sum_{i=1}^{n} p_{i} \log \left(p_{i}\right)
\end{gathered}
$$

Theil(1967)은 엔트로피의 개념이 불평등도와 밀접한 관련이 있다고 보았다. 앞서 언급한 어떠한 사건 i가 발생할 확률이 1 이고 다른 사건들이 발생할 확률이 0 인 경우를 살펴보자. 여기 


\section{주택금융영군ㄱ}

서 발생 가능한 사건들을 사람들로, 사건들의 발생확률을 소득 점유율로 치환하여 보자. 그러면 이 예시는 사람 i가 모든 소득을 점유하고 있고 다른 사람들은 소득이 없는 경우로 치환된다. 엔 트로피가 가장 낮았던 이 경우는 불평등도가 가장 높은 경우가 된다. 반대로 모든 사건들의 발 생확률이 같은 경우를 살펴보자. 이 경우는 모든 사람들의 소득점유율이 같은 경우로 치환된다. 엔트로피가 가장 높았던 이 경우는 불평등도가 가장 낮은 경우가 된다. 타일(Theil)은 이러한 관계에 주목하여 타일 지수를 발생 가능한 가장 높은 엔트로피에서 측정된 엔트로피를 빼는 식 으로 정의하였다(〈식 11〉). 이렇게 정의한 타일 지수는 그 값이 클수록 불평등도가 높고 낮을수 록 불평등도가 낮음을 나타낸다.

$$
\begin{gathered}
T=\sum_{i=1}^{n} \frac{1}{n} h\left(\frac{1}{n}\right)-\sum_{i=1}^{n} s_{i} h\left(s_{i}\right) \\
=\sum_{i=1}^{n} s_{i}\left[h\left(\frac{1}{n}\right)-h\left(s_{i}\right)\right] \\
=\sum_{i=1}^{n} s_{i}\left[\log \left(\frac{1}{n}\right)-\log \left(s_{i}\right)\right] \\
=\frac{1}{n} \sum_{i=1}^{n} \frac{y_{i}}{\bar{y}} \log \left(\frac{y_{i}}{\bar{y}}\right)
\end{gathered}
$$

$s_{i}=\frac{y_{i}}{n \bar{y}}, \quad \sum_{i=1}^{n} s_{i}=1$

타일 지수는 큰 틀에서 일반 엔트로피 불평등도 지수(Generalized Entropy Measures, 이하 GE)의 특수한 경우라고 볼 수 있다. GE는 〈식 12〉와 같이 나타낼 수 있다. 〈식 12〉에서 $\alpha$ 가 1 의 값을 가질 때 $\mathrm{GE}$ 는 타일 지수를 나타낸다. 앞서 SWF에서 $\varepsilon$ 의 값에 따라 불평등도 를 회피하고자 하는 정도를 조절할 수 있었다면, $\mathrm{GE}$ 에서는 $\alpha$ 의 값에 따라 이를 조절한다고 볼 수 있다.

$$
\operatorname{Entropy}(\alpha)=\frac{1}{\alpha(\alpha-1)}\left[\frac{1}{N} \sum_{i=1}^{N}\left[\frac{y_{i}}{\bar{y}}\right]^{\alpha}-1\right]
$$

이 글에서는 주택금융공사(2018)의 방식으로 임차시장의 부담을 측정하되, 주택임차가능지 수 산출 과정에서 도출되는 주택임차가능분포도에서 나타나는 임차 기회의 불평등도를 타일 지 수를 이용해 측정하고자 한다. 


\section{III. 분석방법}

이 장에서는 앞서 언급한 임차가능지수와 임차가능지수를 계산하는 과정에서 도출되는 임차 가능분포도를 이용하여 주거서비스 향유의 불평등도를 측정하는 방법에 대해 논해보고자 한다.

\section{1. 임차가능분포도와 로렌츠 곡선 간 관계}

직관적으로 봤을 때 임차가능분포도는 로렌츠 곡선과 유사한 면이 있지만, 개념적으로는 조 금 차이가 있다. 소득 분포에 대한 로렌츠 곡선의 $y$ 축은 소득의 누적점유율을 나타낸다. $x$ 축의 동일 간격에 포함된 인구수는 항상 동일하며, 오른쪽으로 갈수록 소득이 더 높은 사람들이 분포 되기 때문에, 로렌츠 곡선의 그래프의 기울기는 단조증가함수가 된다. 반면 임차가능분포도의 $\mathrm{y}$ 축은 각 가구들이 전체 주택 대비 부담할 수 있는 주택의 비율을 나타낸다. 로렌츠 곡선과는 달리 누적의 개념이 아니며, 전체 대비 해당 가구가 갖는 점유율의 개념도 아니다. 따라서 임차 가능분포도의 기울기는 단조증가 함수가 아니게 된다. 주택임차가능분포도의 기울기가 단조증 가함수가 아니기 때문에 나타나는 특징은 그래프의 모양과 그래프의 넓이가 더 이상 일대일 관 계가 아니게 된다는 점이다. 즉, 그래프의 넓이가 같더라도 다른 그래프의 모양을 가질 수 있다. 〈그림 2〉에 있는 직선과 곡선 아래의 넓이는 모두 같다. 곡선 그래프에 비해 직선 그래프에는 임차능력이 낮은 계층에게도 더 많은 주거의 기회가 주어진 반면 중상위계층에게 기회가 상대 적으로 적게 주어지면서 어느 정도 균형이 맞춰졌다. 주거기회의 총량에서는 두 경우 모두 동등 하지만, 곡선에 비해 직선의 그 래프가 나타내는 사회가 조금 더 이상적이라고 볼 수 있다. 단순 히 그래프의 넓이를 비교하는 것 만으로는 이러한 분배의 문제를 파악하는데 필요한 정보를 얻지 못한다. 따라서 주택임차가능분 포도에는 로렌츠 곡선의 정보를 파악하는데 사용되는 지니계수 를 적용하기가 어렵다.

\section{<그림 2> 주택임차가능분포도 예시}

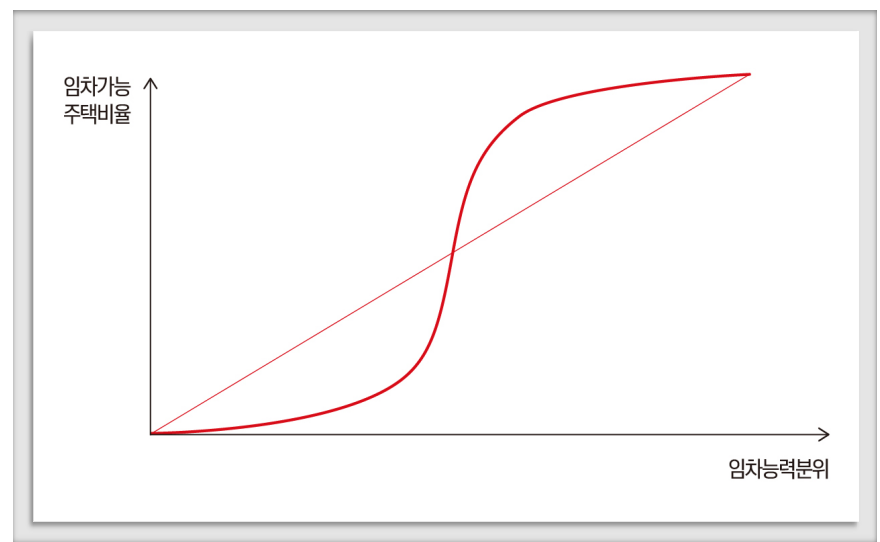




\section{주백금융영군ㄱ}

이러한 문제를 해결하기 위한 한 가지 방법은 임차가능분포도의 정의를 로렌츠 곡선과 같이 바꾸어서 그리는 것이지만, 이에 앞서 우리가 로렌츠 곡선과 지니계수를 통해 보고자 하는 것이 무엇인가에 대하여 생각해 볼 필요가 있다. 지니계수는 어떠한 이론적 근거를 바탕으로 도출된 것이 아니라, 임의로 도출한 로렌츠 곡선의 그래프를 통해서 계산된다. 소득분포에 대한 로렌츠 곡선이 $y=x$ 와 완전히 겹친다는 것은 모든 사람들이 같은 소득을 갖는다는 것이며, 이 때 지니 계수는 최소값을 갖는다. 로렌츠 곡선이 $\mathrm{y}=\mathrm{x}$ 로부터 멀어질수록 지니계수는 상승하게 된다. 지 니계수가 균일한 소득 분포를 기준으로 하므로, 우리가 지니계수를 참고한다는 것은 이 경우가 완벽하게 이상적이지는 않더라도 참고할만한 상태, 혹은 어느 정도 가까울 필요가 있는 상태라 는 것을 전제로 한다는 것을 의미한다. 개인의 노력 및 생산성의 차이에 따른 소득의 불균형은 어느 정도 존재하겠지만, 그 정도가 개인의 능력차 이상이 되는 것은 바람직하지 않다는 것이 다. 임차가능분포도를 로렌츠 곡선과 같이 정의하여 그렸을 때 $\mathrm{y}=\mathrm{x}$ 선과 겹친다는 것은 모든 사 람들이 연 소득과 보유자산의 규모와 무관하게 주거에 대해 완벽하게 같은 수준의 기회를 갖는 다는 것을 의미한다. 연 소득 10 억에 보유자산 30 억인 가구와 연 소득 3 천만 원에 보유자산 4 천만 원인 가구가 같은 수준의 주거기회를 갖는 것이 바람직한 모습인지, 그리고 사회가 그 상 태에서 벗어난 정도를 우리가 보고 싶어 하는 것인지에 대해서는 생각해볼 필요가 있다.

한 사회에 주거의 기회가 균등하게 제공되는지 판단할 때 고려해야할 요소로는 크게 두 가지 를 꼽을 수 있다. 첫째는 앞서 언급한 소득-자산의 분포이며, 두 번째 요소는 주택임차비용의 분포이다. 소득-자산의 격차가 매우 극심해 소수의 고소득층과 다수의 저소득층이 존재하는 사 회일지라도, 이 사회에 존재하는 주택들이 대부분 낮은 임대료를 요구한다면 사람들이 체감하 는 주거기회는 소득-자산에 비해 균등하게 주어진다고 볼 수 있다. 반대로 소득-자산의 격차는 크지 않더라도 수익성 등의 이유로 고급형 주택들만 공급된다면, 사회의 구성원들이 느끼는 주 거기회의 불평등도는 높을 수 있다. 이와 같이 주거의 기회는 소득·자산의 분포와 주택가격의 분포가 동시에 고려되어야 제대로 파악할 수 있다.

이러한 측면에서 볼 때, 앞서 제시된 주택임차가능분포도는 주택시장이 제공하는 주거의 기 회가 얼마나 사회 구성원의 지불능력으로 부담가능한지를 나타낸다고 볼 수 있다. 주택임차가 능분포도는 각 가구들이 자신의 임차능력분위에 해당하는 비율의 주택을 부담할 수 있을 때 $y=x$ 기준선과 일치하게 된다. 이러한 경우에는 소득과 자산 모두를 고려한 지불능력이 하위 $30 \%$ 인 가구는 거래되는 주택의 $30 \%$ 를 부담할 수 있고, 상위 $10 \%$ 인 가구는 $90 \%$ 의 주택을 부 담할 수 있다. 앞서 언급했던 로렌츠 곡선의 기준선과 주택임차가능분포도의 기준선을 비교한 다면, 전자는 주거의 기회가 완전히 균등한 상태를 기준으로 하는 반면 후자는 소득-자산 분위 
대비 주거의 기회가 얼마나 균등한지를 보고자한다.

따라서 이 연구에서는 주택임차가능분포도를 로렌츠 곡선의 정의에 부합하게 바꾸기보다는 주택임차가능분포도는 그대로 유지한 채 지니계수가 아닌 다른 불평등도 측정 지수의 적용 방 법에 대해 다루기로 한다.

한 가지 고려해볼만한 점은 각 가구의 임차가능비율을 자신의 임차능력 분위로 나누어, 각 가 구들이 $y=x$ 에서 얼마나 떨어져 있는지 그 자체를 보는 것이다. 하지만 실제로 이렇게 계산한 결과는 원 임차가능지수와 상관관계가 0.95 가 넘을 정도로 실제로 큰 차이를 보이지 않을 뿐만 아니라, 낮은 임차가능 분위에서는 분모가 너무 작아 전체 평균 지수값이 이 계층에서의 움직임 에 과도하게 민감하게 반응하는 문제점이 발견되었다. 따라서 이 부분에 대한 분석결과는 생략 하였다.

\section{2. 가구의 특성에 대한 고려}

서로 상이한 특징을 가진 가구들의 임차부담을 동일선상에 놓고 비교할 수 있는지 우선 살펴 볼 필요가 있다. 일반적으로 가구원 숫자가 많을수록 더 넓은 주거 면적이 필요하다. 1 인 가구 가 거주하는 원룸에서 4 인가구가 거주할 경우 두 가족이 체감하는 삶의 질은 차이가 발생할 수 밖에 없으므로, 같은 기준으로 두 가구들을 비교하는 것이 적절한지에 대하여는 고민할 필요가 있다. 가구의 형태뿐만 아니라, 가구주의 연령 혹은 가구의 생애주기에 따라서도 필요로 하는 주거지의 면적에 차이가 발생할 수 있다. 같은 4 인 가구라 할지라도 아직 자녀들이 어린 가구에 비해 성인 4 명으로 구성된 4 인 가구는 더 넓은 면적을 필요로 한다. 이런 측면에서 볼 때, 각 가 구들은 자신의 특성에 따라 서로 다른 주택시장의 부분집합에 참여하고 있다고도 할 수 있다.

앞서 언급한대로 주택금융공사(2018)에서는 적정넓이를 정의하고 각 사람들이 실제 참여하 는 주택시장의 부분집합으로 관심을 좁혀 임차부담을 측정하였다. 각 가구가 필요로 하는 적정 넓이란 매우 주관적일 수밖에 없다. 적정하다는 것은 일정 수준 이상의 삶의 질을 유지하기 위 해 필요하다는 것인데, 그 일정 수준이라는 것이 객관적으로 정의할 수 없을 뿐만 아니라 경제 가 발전하고 가구의 평균소득이 증가하면 가구의 눈높이 또한 올라가 요구하는 수준이 높아질 수 있다. 따라서 주택금융공사(2018)에서는 비슷한 형태의 가구들이 실제로 점유하고 있는 거 주지의 넓이 분포를 분석하여 넓이 기준으로 상위 $40 \%-60 \%$ 의 가구들이 살고 있는 곳의 넓이 구간을 적정넓이로 정의하였다(〈표 1〉). 이렇게 정의할 경우 각 가구가 최소한의 삶의 질을 유 
지하기 위한 주거지라기보다는 현 시점에서 비슷한 특징을 가진 가구들과 비교하여 평균적인 수준의 주거지를 점유하고자 할 때 체감하는 부담을 측정하게 된다.

<표 1> 지역별 각 가구형태의 적정면적

단위: $\mathrm{m}^{2}$

\begin{tabular}{c|c|c|c|c|c}
\hline \multicolumn{2}{c|}{2016} & & 전국 & 수도권 & 비수도권 \\
\hline \multirow{3}{*}{ 1인 } & $40 \%$ & 41 & 33 & 50 \\
\cline { 2 - 5 } & $60 \%$ & 56 & 46 & 60 \\
\hline \multirow{2}{*}{2 인 } & $40 \%$ & 60 & 59 & 66 \\
\cline { 2 - 5 } & $60 \%$ & 82 & 76 & 83 \\
\hline \multirow{2}{*}{3 3인 } & $40 \%$ & 66 & 61 & 66 \\
\cline { 2 - 6 } & $60 \%$ & 84 & 83 & 84 \\
\hline \multirow{2}{*}{4 인 이상 } & $40 \%$ & 79 & 74 & 85 \\
\cline { 2 - 6 } & $60 \%$ & 85 & 85 & 79 \\
\hline
\end{tabular}

자료 : 주택금융공사(2018)

이러한 방식으로 부담을 측정했을 때 생길 수 있는 문제점은 주택시장에 존재하는 각 부분집 합에 공급되는 물량에 차이가 있다는 점이다. 〈표 2〉는 가구원수와 지역에 따라 가구를 분류하 였을 때, 2016년 기준 전체 주택 대비 적정면적 주택의 비율을 나타내고 있다. 2016년에는 시 장에 1 인, 2 인 가구가 거주할만한 주택은 각각 3 인, 4 인 가구가 평균적으로 거주하고 있는 넓 이의 주택의 두 배 정도가 거래되고 있음을 알 수 있다. 〈표 3〉에는 같은 시기 각 형태의 가구들 의 비율을 나타낸 것이다. 1 인, 2 인, 4 인 가구들 간 비율의 차이가 그리 크지 않음을 확인할 수 있다. 2 인 가구와 4 인 가구 간 숫자는 크게 차이가 나지 않지만 시장에 공급되고 있는 적정면적 주택의 비중은 2 배 이상의 차이가 나고 있다. 만약 2 인가구와 4 인가구의 평균 부담가능주택/적 정면적주택 비율이 같다고 하더라도, 각 가구들이 참여하는 시장 부분집합에 공급되는 주택의 숫자가 다르기 때문에 각 가구들이 갖게 되는 주거의 기회는 다르다고도 볼 수 있다.

<표 2> 지역별 전체 주택 대비 적정면적 주택의 비율

\begin{tabular}{c|c|c|c|c}
\hline & 1인 가구 & 2인 가구 & 3인 가구 & 4인 가구 \\
\hline 전국 & $17.64 \%$ & $20.71 \%$ & $8.76 \%$ & $9.36 \%$ \\
\hline 수도권 & $17.43 \%$ & $19.66 \%$ & $8.13 \%$ & $8.83 \%$ \\
\hline 비수도권 & $18.00 \%$ & $22.58 \%$ & $9.86 \%$ & $10.30 \%$ \\
\hline
\end{tabular}

자료 : 주택금융공사(2018) 
<표 3> 지역별 각 가구형태의 비율

\begin{tabular}{c|c|c|c|c} 
& 일반가구 & 1인 가구 & 2인 가구 & 3 인 가구 \\
\hline 전국 & $100.00 \%$ & $27.87 \%$ & $26.16 \%$ & $21.44 \%$ \\
\hline 수도권 & $100.00 \%$ & $26.37 \%$ & $24.57 \%$ & $22.50 \%$ \\
\hline 비수도권 & $100.00 \%$ & $29.26 \%$ & $27.64 \%$ & $20.45 \%$ \\
\hline
\end{tabular}

자료 : 주택금융공사(2018)

민병철 외(2018)에서 시도한 방식과 주택금융공사(2018)에서 시도한 방식에는 이러한 일장 일단이 있기 때문에 이 글에서는 각각에 대하여 주거기회에 대한 불평등도를 계산하여 비교하 여 보기로 한다.

\section{3. 불평등도의 분해}

가구들을 부분집합으로 나누어서 분석한다면, 가구간 발생하는 불평등도의 주요한 원천은 두 가지로 생각해 볼 수 있다. 첫 번째는 각 부분집합 내에서 소득과 자산의 차이로 인해 발생하는 불평등도이다. 같은 50 대 가구주의 4 인 가구라 할지라도 소득과 자산이 많은 가구와 적은 가구 의 주거의 기회는 차이가 날 것이다. 두 번째는 부분집합 간에 발생하는 불평등도이다. 각 부분 집합들이 필요로 하는 주택의 면적은 같지 않으므로, 이들이 참여하고자 하는 주택시장의 가격 및 공급도 다를 수밖에 없다. 주택금응공사(2018)에서는 3인, 4 인 가구에 비해 1 인 가구의 임 차부담이 크다는 것을 발견하였다. 이러한 부분집합 간 차이가 시간에 따라 어떻게 달라지는지 를 분석하는 것도 의미가 있다.

부분집합 단위의 분석을 위해 타일 지수는 다음과 같이 분해할 수 있다.

$$
\begin{aligned}
& T=\sum_{i=1}^{N} \frac{y_{i}}{\overline{N y}} \ln \left(\frac{y_{i} N}{\overline{N y}}\right) \\
& =\sum_{i=1}^{N} \frac{y_{i}}{Y} \ln \left(\frac{y_{i} N}{Y}\right) \\
& =\sum_{j}\left(\frac{Y_{j}}{Y}\right) T_{j}+\sum_{j}\left(\frac{Y_{j}}{Y}\right) \ln \left(\frac{Y_{j} / Y}{N_{j} / N}\right)
\end{aligned}
$$




\section{주택금융연구}

$T$ 는 전체 표본에 대한 타일 지수, $T_{j}$ 는 $\mathrm{j}$ 번째 부분집합에 대한 타일 지수, $y_{i}$ 는 i번째 표본의 부의 양, $Y_{j}$ 는 $\mathrm{j}$ 번째 부분집합의 총 부의 양, $\bar{y}$ 는 개인의 평균 부의 양, $Y$ 는 전체 표본의 총 부 의 양, $N_{j}$ 는 j번째 부분집합의 표본 수, $N$ 은 전체 표본의 수를 나타낸다. 〈식 13〉의 첫 번째 항 은 부분집합 내의 불평등도를 나타내며 두 번째 항은 부분집합 간 불평등도를 나타낸다. 이 글 에서는 지역별(특별시, 광역시, 도 단위)/가구원수(1인, 2인, 3인, 4인 이상)/가구주의 나이(39 세 이하, 40-69세, 70세 이상)로 부분집합을 나누었다. 부분집합의 총 개수는 $16 \times 4 \times 3=192$ 개이다. 이렇게 분해하면 소득과 자산의 불균형으로 인해 발생하는 주거기회의 불평등도와 지 역별, 가구형태에 따른 주거기회의 불평등도로 나누어서 분석할 수 있다.

물론 여기서 말하는 가구형태와 소득-자산은 완전히 독립적이지는 않다. 젊은층의 소득과 자 산은 자신들의 자녀계획에 영향을 미쳐 가구의 크기를 변화시킬 수 있다. 하지만 이 영향은 뚜 렷하지 않아, 소득이 많을수록 더 많은 자녀를 부양할 여유가 생기지만 반대로 고소득을 올리는 전문직 맞벌이 부부의 경우 자녀를 부양할 시간적 여유가 적어 자녀를 적게 가질 가능성도 있 다. 어느 쪽의 영향력이 크게 나타날지는 이 글에서 다루는 범위를 벗어난다. 하지만 이 글에서 다루는 2012 2017년의 기간 내에서는 그 영향의 방향성이 크게 바뀔 것이라고 보기 어려우므 로, 시계열의 변화만을 관찰한다면 이러한 영향을 무시할 수 있을 것이다.

\section{4. 분석과정}

이 글에서는 우선 민병철 외(2018)와 주택금융공사(2018)에서 사용한 분석 방법을 따르되, 전체가구가 아닌 임차가구로 분석의 대상을 제한하였다. 임차가능지수는 각 가구의 현재 자산 및 소득으로 이사를 간다고 가정했을 때 전체 임차시장에서 부담할 수 있는 주택의 비율을 계산 한다. 자가 소유자들은 이사를 위해 자신의 현재 주택을 처분할 경우 임차시장에서 전세 혹은 월세를 어렵지 않게 구할 수 있어 이들의 부담은 낮게 측정이 될 것이다. 하지만 이들은 임차시 장의 주된 참여자들이라고 보기 어려우며, 이들의 주거부담은 임차시장이 아닌 매매시장에서 측정하는 것이 적절할 것이다. 각 임차가구가 부담 가능한 주택의 비율을 $\mathrm{f}(\mathrm{x})$ 라 하고 각 가구에 대한 가중치를 $\mathrm{w}(\mathrm{x})$ 라 하면, 주택임차가능지수는 〈식 14 >와 같이 나타낼 수 있다. 해석의 편의 성을 위해 상수 200 을 곱하게 된다.

$$
\text { Affordability }=200 \times \int f(x) w(x) d x
$$


임차가구로 분석의 대상을 제한한 후 먼저 전국 단위의 임차가능지수를 지역별 임차가능지수 의 가중평균값과 비교를 할 필요가 있다. 이 때 가중평균은 지역별 가구수의 비율을 가중치로 이용한다. 전국 단위의 임차가능지수를 계산하는 것은 모든 가구들이 전국 모든 주택을 대상으 로 임차할 수 있는지를 보는 것이고, 지역별 임차가능 지수는 각 지역의 가구들이 해당 지역의 주택을 임차할 수 있는지를 보는 것이다. 직장문제, 가족 문제 등으로 삶의 터전을 옮기기는 쉽 지 않다는 점을 고려하면 지역별로 임차가능지수를 계산한 후 이를 가중평균 내는 것이 더 적절 할 수 있으나, 단순히 전국단위로 계산하는 것과 큰 차이가 나지 않는다면 굳이 복잡한 계산방 식을 택할 필요가 없을 수도 있다. 각 지역에 대하여 계산된 임차가능지수를 Affordability , $_{i}$ 전국 대비 각 지역의 인구비중을 $w_{i}$ 라 하면 이렇게 계산된 임차가능지수는 〈식 15 〉와 같이 나 타낼 수 있다.

$$
\text { Affordability }=\sum_{i} w_{i} \text { Affordability }_{i}
$$

이렇게 산출한 지수와 주택금융공사(2018)에서 사용한 방식으로 계산한 지수를 비교하였다. 각 가구형태에 대하여 적정한 넓이 범위를 부여하고 이 넓이에 해당하는 주택만을 대상으로 임 차가능지수를 계산한다면, 1 인, 2 인 가구들의 경우에는 넓은 주택들이 제외가 되며 4 인 가구의 경우에는 좁은 원룸 등이 제외가 된다. 전자는 지수를 상승시키는 요인이며 후자는 감소시키는 요인인데, 전체적으로 어느 영향이 더 크게 나타날지는 미리 알기 어렵다. 가구의 특성을 고려 하여 계산한 지수를 categorized Affordability라 하면 지역을 고려하지 않은 경우는 〈식 16〉 과 같이, 지역까지 고려한 경우는 〈식 17〉과 같이 나타낼 수 있다.

$$
\text { categorized Affordability }=\sum_{j} \sum_{k} w_{j, k} \text { categorized Affordability } \text { f }_{j, k}
$$

j: 1인, 2인, 3인, 4인이상 가구, k: 가구주 연령 39이하, 40-69, 70이상

$$
\text { categorized Affordability }=\sum_{i} \sum_{j} \sum_{k} w_{i, j, k} \text { categorized Affordability } y_{i, j, k}
$$

$\mathrm{i}:$ 특별시, 광역시, 도, $\mathrm{j}: 1$ 인, 2인, 3인, 4 인 이상 가구,

$\mathrm{k}$ : 가구주 연령 39이하, 40-69, 70이상

다음은 상술한 방식으로 계산된 지수들에 대하여 타일 지수를 계산하였다. 타일 지수는 로그 
함수를 사용하기 때문에 입력값들이 모두 양수인 경우에 대하여만 계산이 가능한데, 이 연구의 계산방식을 따르면 임차능력이 떨어지는 가구들은 임차가능 비율이 0이 되어 계산이 불가능해 진다. Morrisson(2007) 에서는 [0,M]에 대해 정의된 확률변수 $\mathrm{X}$ 의 분포 $\mathrm{f}$ 가 있을 때 이를 $\mathrm{X}>0$ 에 대한 분포 $\mathrm{g}$ 와 $\mathrm{X}=0$ 에 대한 분포로 분해할 수 있으며(〈식 18〉), 이 때 전체 표본의 타일 지 수 Theil(f)는 〈식 19>와 같이 나타낼 수 있음을 보였다. 이 글에서도 이 방식을 따라 타일 지수 를 계산하였다.

$$
\begin{gathered}
f(x)=p \delta_{x=0}+(1-p) g(x) \\
\text { Theil }(f)=\operatorname{Theil}(g)-\ln (1-p)
\end{gathered}
$$

\section{IV. 사용자료}

가계의 소득, 자산 및 부채 자료는 가계금융복지조사의 마이크로데이터 및 공식 공표 자료를 사용하였다. 주택 정보는 국토교통부에서 제공하는 실거래정보를 이용하였으며, 인구 구성 관 련 정보는 통계청의 인구총조사 자료를 사용하였다. 대상 기간은 2012 2017년이다.

\section{$\mathrm{V}$. 분석결과}

<표 4> 분석 결과 1

\begin{tabular}{c|c|c|c|c}
\hline 연도 & \multicolumn{1}{|c|}{$(\mathbf{1})$} & \multicolumn{1}{|c}{$(2)$} & \multicolumn{1}{c}{$(3)$} & \multicolumn{1}{c}{$(\mathbf{4})$} \\
\hline 2012 & 93.6304 & 99.8739 & 84.2238 & 92.4664 \\
\hline 2013 & 101.0157 & 107.2677 & 89.4579 & 98.5088 \\
\hline 2014 & 101.6122 & 108.2557 & 88.1093 & 98.1662 \\
\hline 2015 & 104.4840 & 111.1773 & 90.5367 & 100.8731 \\
\hline 2016 & 100.4414 & 106.5048 & 87.4721 & 98.0090 \\
\hline 2017 & 99.8440 & 107.8786 & 86.9539 & 98.5000 \\
\hline
\end{tabular}

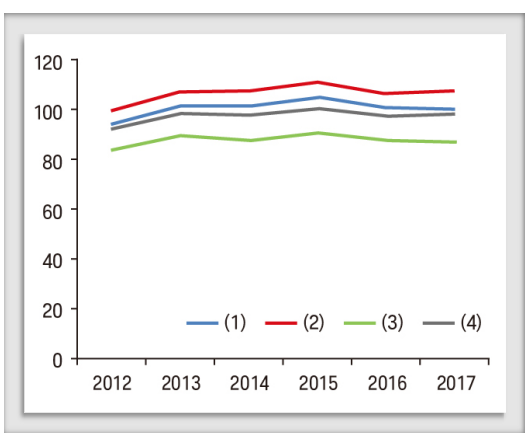


〈표 4〉의 첫 번째 열에는 〈식 14 〉를 계산한 결과를 나타내었다. 지수가 상승할수록 가구가 부담할 수 있는 주택의 비율이 높은 것이므로 가구의 주거부담이 낮아지는 것을 의미한다. 지수 는 2012년에서 2015년까지 상승하였다가 이후로 감소하는 양상을 나타내는데, 이는 전반적인 금리 움직임과 임차시장의 가격변화를 반영한 것으로 보인다.

두 번째 열에는 〈식 15〉의 결과를 나타내었다. 지역 구분이 없었던 〈식 14〉와 전반적인 움직 임은 유사하나, 〈식 14 〉의 결과와 비교하여 지수의 값이 상당히 높아진 것을 볼 수 있다. 이는 수도권 지역의 값비싼 주택들이 타 지역의 지수를 계산할 때 제외된 효과가 크기 때문인 것으로 해석된다. 다시 말해, 사람들이 거주지만을 찾아 삶의 터전을 옮기기는 쉽지 않은 현실을 감안 한다면 전국 단위로 움직이는 경우보다 전체적인 임차부담이 낮게 평가된다는 것이다.

세 번째 열에는 〈식 16)과 같이 지역구분 없이 가구원수, 세대주의 나이로 적정넓이의 개념 을 적용하여 계산한 결과를 나타낸다. 첫 번째 열과 비교하여 움직임의 방향은 비슷하나 지수의 값 자체는 크게 감소한 것을 볼 수 있다. 이 결과는 가구가 전체 주택이 아닌 자신과 비슷한 가 구원수, 연령대의 가구들이 점유하는 주거지의 넓이 범위의 주택을 임차하는 것이 얼마나 용이 한지를 파악한 것이다. 첫 번째 열과 비교하여 지수가 크게 감소한 것은, 첫 번째 열의 결과에는 3 인, 4 인 가구들이 살기에는 좁은 넓이의 원룸 등이 모두 포함되어 있기 때문인 것으로 해석된 다. 이 열의 결과는 이러한 주택들을 제외하고 주거부담을 파악한다면 그렇지 않은 경우와 비교 하여 차이가 상당히 큼을 나타낸다.

네 번째 열은 가구별 특성에다 지역별 차이를 고려한 〈식 17〉의 결과를 나타낸다. 첫 번째 열 과 두 번째 열의 관계와 유사하게, 움직임 자체에는 큰 차이가 없지만 지역별 차이를 고려할 경 우 전체적으로 부담이 다소 감소하는 것으로 나타난다. 이는 앞서 언급한 바와 같이 수도권에 있는 고가의 주택들이 다른 지역의 부담을 계산할 때 제외된 영향인 것으로 해석된다.

\section{<표 5> 분석 결과 2}

\begin{tabular}{c|c|c}
\hline 연도 & $(1)$ & (2) \\
\hline 2012 & 0.3060 & 0.4246 \\
\hline 2013 & 0.2666 & 0.3834 \\
\hline 2014 & 0.2562 & 0.3789 \\
\hline 2015 & 0.2424 & 0.3560 \\
\hline 2016 & 0.2560 & 0.3733 \\
\hline 2017 & 0.2614 & 0.3341 \\
\hline
\end{tabular}

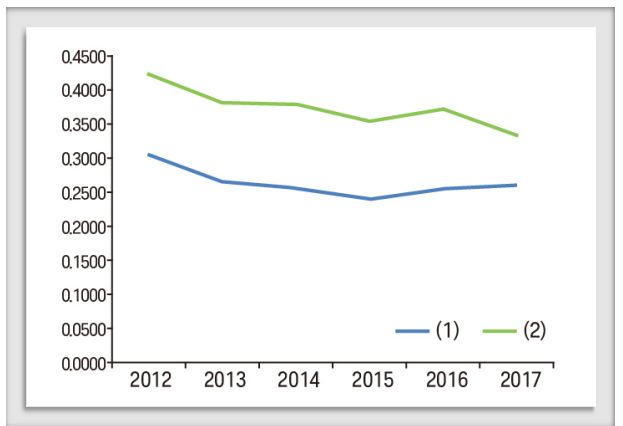




\section{주백금융영군ㄱ}

〈표 5〉에는 위에서 계산한 지수들에 대한 불평등도를 〈식 19〉와 같이 계산한 결과를 나타내 었다. 결과값이 클수록 불평등의 정도가 더 높다는 것을 의미한다. 첫 번째 열은 〈표 4〉의 첫 번 째 열과 마찬가지로 지역이나 부분집합 구분 없이 도출된 임차가능분포도에 대한 불평등도가, 두 번째 열은 지역과 부분집합 구분을 고려하여 계산된 불평등도가 나타나 있다. 먼저 눈에 띄 는 것은 두 가지 방법을 통해 계산된 불평등도는 상당한 차이를 보인다는 것이다. 앞서 〈표 4〉 에서는 가구별 특성을 고려하여 좁은 면적의 주택들을 제외하고 지수를 계산할 경우 그렇지 않 은 경우와 비교해 부담 가능한 주택의 비율이 낮아진다고 나타났다. 가구별 특성을 고려하더라 도 각 부분집합들에서 부담 가능한 주택의 비율이 비슷한 정도로 감소한다면 두 경우에 있어 불 평등도는 크게 차이가 나지 않을 것이다. 하지만 소득이 적은 일부 고령층의 가구들은 임대료가 싼 작은 주택만을 부담할 수 있어 이러한 주택들을 제외시킨다면 부담 가능한 주택의 비율이 크 게 감소하게 된다. 다시 말해, 적정넓이의 개념을 적용하여 계산할 경우, 임차능력이 부족해 좁 은 면적의 주택만을 부담할 수 있는 계층들은 자신들이 부담 가능한 주택들이 대거 제외된 채 지수가 계산되므로 다른 계층들에 비교해 상대적으로 지수의 감소폭이 더 커진다. 이는 반대로 표현하면 해당 계층들은 현재 임대료 부담으로 다소 낮은 수준의 주택에 머무르고 있는 비율이 높다고도 할 수 있다. 이러한 결과로 전체적인 불평등도는 높아지게 된다.

계산된 불평등도의 시계열적 흐름을 살펴보면, 첫 번째 열에서는 2012-2015년 사이 불평등 도가 감소하다가 이후는 다소 높아지고 있음을 나타낸다. 두 번째 열에서는 2012-2016까지는 비슷한 흐름을 보이지만, 2017년에는 다소 감소하는 보습을 보인다. 불평등도의 변화를 이해 하기 위해서는 주택임차가능분포도를 살펴볼 필요가 있다. 〈그림 3〉의 좌측에는 연도별 임차가 능분포도를, 우측에는 임차능력 분위별로 전년 대비 차이를 나타내었다. 2013년에는 전년 대 비 중하위 계층을 중심으로 부담 가능한 주택의 비율이 크게 증가했으며, 이러한 경향은 2015 년까지 계속되었다. 2016년에는 중하위 계층에서 특히 부담 가능한 주택의 비율이 감소했는데, 이 영향으로 불평등도가 높아진 것으로 보인다. 2017년에는 중위 계층에서는 부담 가능한 비 율이 높아졌지만 하위 $5 \%$ 13\% 계층에서 낮아지는 보습을 보여 전체적인 불평등도는 다소 높 아진 것으로 나타났다. 


\section{<그림 3> 연도별 주택임차가능분포도}
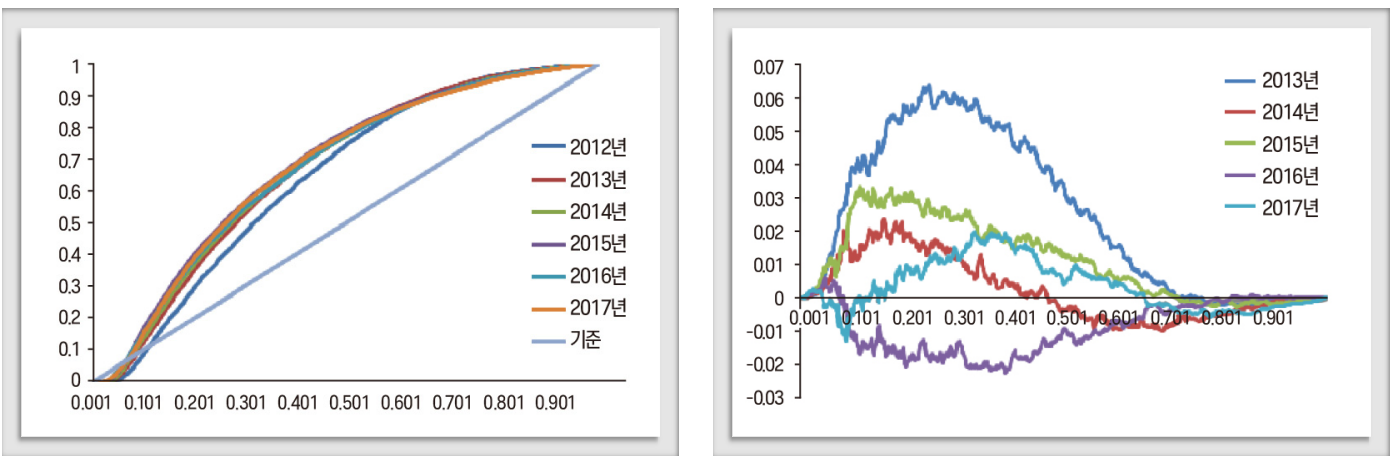

하지만 부분집합을 적용하여 계산한 주거기회의 불평등도 지수에서는(〈표 5〉의 (2)) 2017년 에 상승하는 모습이 보이지 않아 두 가지 방법으로 계산한 지수가 상이한 움직임을 보이는데, 여기에는 두 가지 이유를 생각해 볼 수 있다. 첫 번째는 주택시장의 부분적인 움직임이다. 부분 집합을 적용하여 계산할 경우 분석 대상은 전체 주택시장이 아닌 일정 넓이 범위의 주택들로 한 정된다. 만약 해당 주택들의 가격이 상대적으로 더 상승하거나 하락한다면 전체 주택을 대상으 로 작성된 지수와 다른 움직임을 보일 수도 있다. 두 번째는 계산방식에서 기인하는 시계열적 불안정성이다. 현재 채택한 방식은 각 연도의 가계금융복지조사를 통해 각 형태의 가구들이 살 고 있는 곳의 넓이의 분포를 파악한 후, 40 60\% 범위에 있는 주택을 분석의 대상으로 삼는 것 이다. 이는 평균적인 삶의 질을 평가하기 위한 절대적인 기준을 찾기 힘든 상황에서 상대적인 기준을 적용하고자 하였기 때문이다. 하지만 이 방식으로 인해 매년 적정 넓이 범위가 조금씩 달라져 통계적 불안정성이 생길 우려가 다소 있다. 어느 방식이 더 현실을 적절하게 반영하는지 파악하기 위해서는 향후 추가적인 분석이 필요할 것으로 보인다.

\section{<표 6> 분석 결과 3}

\begin{tabular}{c|c|c|c}
\hline 연도 & 부분집합 간 (1) & 부분집합 내 (2) & 전체 (3) \\
\hline 2012 & 0.0780 & 0.3028 & 0.4246 \\
\hline 2013 & 0.0797 & 0.2633 & 0.3834 \\
\hline 2014 & 0.0888 & 0.2562 & 0.3789 \\
\hline 2015 & 0.0908 & 0.2465 & 0.3560 \\
\hline 2016 & 0.0980 & 0.2541 & 0.3733 \\
\hline 2017 & 0.0809 & 0.2315 & 0.3341 \\
\hline
\end{tabular}

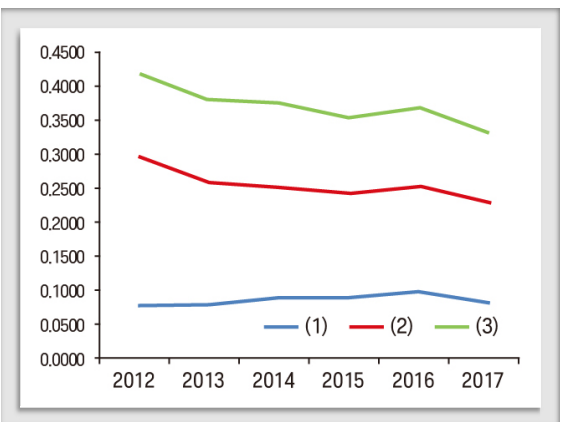


그렇다면 이러한 주거기회의 불평등도는 어디에서 기인하고 있는지 조금 더 자세히 살펴볼 필요가 있다. 〈표 6〉에는 〈표 5〉의 두 번째 열에 계산된 불평등도를 부분집합 내 불평등도와 부 분집합 간 불평등도를 분해한 결과를 나타내었다. 부분집합 내 불평등도는 자산과 소득 간 불균 형으로 나타난다고 볼 수 있으며, 부분집합 간 불평등도는 지역별, 연령대, 가구원수에 따른 불 평등도를 나타낸다. 우선 부분집합 내 불평등도가 부분집합 간 불평등도보다 전체 불평등도에 서 차지하는 비중이 크다는 것을 볼 수 있다. 하지만 이 결과를 두고 자산 소득간 차이가 기여하 는 정도가 다른 요소들에 비해 3 4배에 달한다고 결론짓기에는 다소 무리가 있다. 계산된 불평 등도의 상대적인 크기는 선택한 계산방식에 영향을 받아, 다른 방식을 택한다면 그 중요도가 달 라질 수 있기 때문이다.

주목할 만한 부분은 시간의 흐름에 따라 부분집합 간 주거기회의 불평등도가 증가하고 있다 는 점이다. 이는 지역별, 연령대별, 가구 특성별 임차부담의 격차가 확대되고 있다는 것을 의미 한다. 세부적으로 살펴보면, 제주의 노령층 4인 이상 가구의 임차가능지수는 2012년에서 2017년 사이 42.94가 감소하며 가장 큰 폭의 하락을 나타냈다. 같은 시기 서울, 인천, 경기도 의 노령층 4 인 이상 가구 또한 각각 $29.78,33.2,27.75$ 가 감소하며 높은 하락폭을 나타냈다. 높은 하락폭을 나타낸 다른 계층으로는 젊은층의 2 인가구를 꼽을 수 있다. 신혼부부들이 많을 것으로 추정되는 이 계층은 서울, 인천, 울산, 제주에서 각각 $26.85,21.09,21.8,19.52$ 의 지 수 하락폭을 나타내었다. 마찬가지로 신혼부부들이 많을 것으로 추정되는 젊은층의 3 인 가구는 부산, 대구, 대전, 충북, 전북, 경남에서 임차가능지수가 각각 $35.65,34.44,41.05,45.77$, 36.27 이 상승하며 지역별 차이가 확대되고 있음을 나타냈다.

\section{VI. 결론}

이 글에서는 주택임차가능지수를 이용하여 주거의 기회가 얼마나 고르게 분배되고 있는지를 분석하고자 하였다. 먼저 지역, 가구주의 연령, 가구원수 등을 고려할 경우와 그렇지 않을 경우 를 비교한 결과 상당한 차이가 나타나 지역별, 가구의 특성별로 주거의 기회가 차이가 있음을 확인할 수 있었다. 다음으로 주택임차가능지수에 대하여 불평등도의 척도인 타일지수를 계산한 결과, 전체적으로 주거기회의 불평등도는 시간이 흐름에 따라 감소하는 추세인 것으로 나타났 다. 불평등도의 원천을 분해하여 분석한 결과, 비슷한 계층 내에서 자산 소득으로 인한 불평등 
도는 감소하는 반면 지역별, 가구 특성별 불평등도는 점차 높아지는 것으로 나타났다. 이러한 변화는 주거에 대한 문제는 지역과 가구의 특성을 모두 고려하여 더 정밀하게 분석될 필요가 있 음을 시사한다.

\section{참교문헌}

1. 민병철, 백인걸, 최영상, “지역별 임차부담 측정을 위한 지수개발에 관한 연구.", 주택연구, Vol.26. No. 3, 2018, pp.155-177

2. 주택금융공사, "임차가능지수 및 분포도를 활용한 가구규모별 부담의 측정", 2018

3. Christian Morrisson, Fabrice Murtin. Education inequalities and the Kuznets curves: a global perspective since 1870. PSE Working Papers n²007-12. 2007.

4. Donaldson, D., and Weymark, J.A., "A single-parameter generalization of the Gini indices of inequality.", Journal of economic Theory, Vol. 22. No. 1, pp. 67-86

5. Fisher, R. A., "On the mathematical foundations of theoretical statistics", Philos. Trnas. Roy. Soc. London A., 222(594-604), 1922, pp. 309-368

6. Gan, Quan, and Robert J. Hill, "Measuring housing affordability: Looking beyond the median." Journal of Housing economics, Vol. 18 No. 2, 2009, pp. 115-125.

7. Gini, Corrado. "Italian: Variabilita e Mutabilita (Variability and Mutability)." Cuppini, Bologna, 1912.

8. Lorenz, Max O. "Methods of measuring the concentration of wealth." Publications of the American statistical association 9.70, 1905, pp. 209-219.

9. Shannon, C. E., "A mathematical theory of communication", Bell system thechnical journal, Vol. 27 No 3, 1948, pp. 379-423

8. Theil, H., Economics and information theory. 1967

- 논문접수일 : 2018. 11. 2.

- 1차 수정일 : 2018. 11. 23.

- 게재확정일 : 2018. 12. 14. 